\title{
TWO NEW GUINEAN FICUS SPECIES (MORACEAE): ONE NEW AND THE OTHER WITH AN EMENDED DESCRIPTION
}

\author{
C.C. BERG \\ Bergen Museum, University of Bergen, Allégate 41, 5007 Bergen, Norway; \\ Nationaal Herbarium Nederland, University Leiden branch, \\ P.O. Box 9514, 2300 RA Leiden, The Netherlands; berg@nhn.leidenuniv.nl
}

\section{SUMMARY}

Ficus paoana C.C. Berg is described as a new species and the description of $F$. saruensis C.C. Berg is emended.

Key words: Moraceae, Ficus, Papua New Guinea.

\section{INTRODUCTION}

In the process of handling unidentified Ficus material from Papua New Guinea a new species was discovered and also specimens of $F$. saruensis different from those on which the species was based.

Ficus paoana C.C. Berg, spec. nov. - Fig. 1

Ficos molliore similis, nervis intercostalibus nemerosioribus, stipules longiores differt. - Typus: Bau LAE 82623 (holo LAE; iso K, L), Papua New Guinea, Morobe Province, Waria Valley, Pao River, 80 m, 14 June 1999.

Tree of medium size with tortuous branchlets in zigzag and with Terminalia-branching. Leafy twigs 3-8 mm thick, brown hirsute to subvillous, without nodal glands; internodes solid; periderm persistent. Leaves spirally arranged, \pm tufted; lamina obovate to subobovate to oblanceolate, $14-30$ by $7-14 \mathrm{~cm}$, (almost) symmetric, (sub)coriaceous, apex acuminate, base (sub)cordate, margin (sub)entire; upper surface glabrous, smooth, lower surface brown sericeous on the main veins and sparsely minutely whitish appressed-puberulous on the smaller veins, smooth, cystoliths above and beneath; lateral veins 9-13 pairs, some or several of them furcate away from the margin, below the main basal pair 1-3 pairs of smaller veins, tertiary venation scalariform with in the middle of the lamina up to c. 20 parallel intercostals; waxy glands in furcations of lateral veins; petiole 1-3 cm long, brown hirsute to subvillous, the epidermis persistent; stipules $2.5-3.5 \mathrm{~cm}$ long, glabrous, (sub) persistent, becoming deflexed. Figs axillary, solitary, or on up to $5 \mathrm{~cm}$ long leafless branchlets on the trunk (?), subsessile or with a peduncle up to $0.3 \mathrm{~cm}$ long; basal bracts 3 , subverticillate, $1.5-2.5 \mathrm{~mm}$ long; receptacle subglobose, $0.8-1.3 \mathrm{~cm}$ diam. when dry, \pm densely brown puberulous to subvillous, 


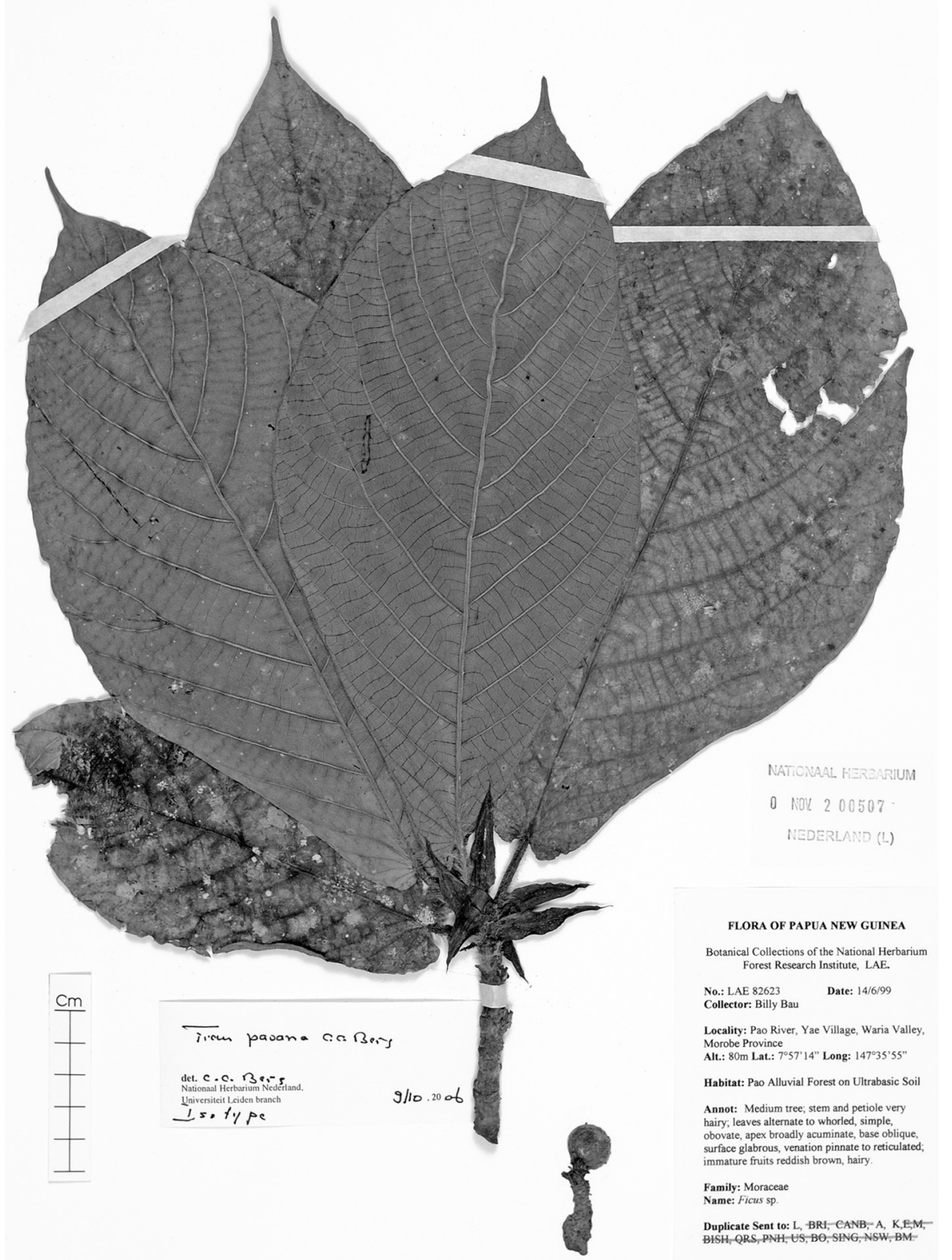

Fig. 1. Ficus paoana C.C. Berg. Leafy twig and fig-bearing branchlet (B. Bau LAE 82623, L), Papua New Guinea, Province Morobe, Waria Valley, Pao River. 
without or with 1 or 2 lateral bracts, slightly ribbed, colour at maturity unknown, apex \pm convex, ostiole c. $3 \mathrm{~mm}$ diam., surrounded by 5 thickened apical bracts, umbonate; internal hairs present, brownish.

Distribution - Papua New Guinea, Morobe Province, Waria Valley; forest on ultra basic alluvial soil, at c. $80 \mathrm{~m}$ altitude.

Notes -1 . This species belongs to subg. Sycomorus sect. Adenosperma, showing affinities to F. mollior Benth., from which it differs in the $2.5-3.5 \mathrm{~cm}$ long subpersistent vs $0.5-1.5(-2.5) \mathrm{cm}$ long mostly caducous stipules and the more numerous parallel intercostals in the middle of the lamina, up to c. 20 vs up to c. $10(-12)$, which is also the maximum number for other New Guinean Adenosperma species with scalariform tertiary venation.

2. The collections are made in Hie or Hose Alluvial forest on ultrabasic soil, which may imply that the species is a local (?) endemic adapted to ultra basic soil conditions.

3. It can be keyed out with the Flora Malesiana Regional Key for subg. Sycomorus in New Guinea (Berg \& Corner, 2005: 332-333) by adding this new lead 17:

17a. Tertiary venation scalariform with up to c. 20 parallel intercostals in the middle part of the lamina; stipules subpersistent, becoming deflexed ...... F. paoana

b. Tertiary venation reticulate, or if scalariform, then with up to $10(-12)$ parallel intercostals in the middle part of the lamina; stipules caducous or if subpersistent,

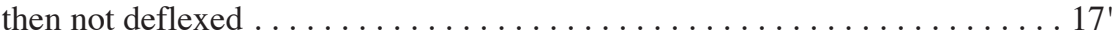

Note: all leads after this new lead 17 can be distinguised by adding ' to the number. Also note that lead 8b now keys out to lead 17'.

Additional collections examined:

Bau LAE 82665 (K, L), LAE 82702 (K, L) and LAE 82725 (K), Papua New Guinea, Morobe Province, Waria Valley, Pao River, 80 m, 14-15 June1999; Lovave LAE 82378 (L), Papua New Guinea, Morobe Province, Waria Valley, Hose Creek, 80 m, 12 June 1999.

\section{Ficus saruensis C.C. Berg}

Ficus saruensis C.C. Berg (2003) 294; Berg \& Corner (2005) 157.

Examination of additional material showed that the species can be (sub)glabrous on leafy twigs and leaves as in: Takeuchi et al. $14569(\mathrm{~K})$ and $14584(\mathrm{~K})$ from Papua New Guinea, Morobe Province, Kamiali Wildlife Management area, or only the leaves as in Takeuchi et al. 14491 (L) and 15568B (L) from the same area. On the other hand, it also showed that the brown tomentose indumentum can occur on the fig receptacle and even on the upper ostiolar bracts, at least in the young state of the fig: Takeuchi et al. 15210 (K), Papua New Guinea, Morobe Province, Kamiali Wildlife Management area or as in Takeuchi et al. 15401 (L) from the same area in which the indumentum on the main veins beneath disappears.

This species is one of the two New Guinean species of subg. Pharmacosycea sect. Oreosycea with sessile, non-stipitate figs with the receptacle $0.6-1.3 \mathrm{~cm}$ diam. when dry. The other species, F. subtrinervia Lauterb. \& K. Schum. is distinct by its tertiary venation running largely parallel to the lateral veins. 
Emended description - Tree up to $15 \mathrm{~m}$ tall. Branchlets drying (dark) brown. Leafy twigs 1.5-3 mm thick, solid, \pm angular, brown subtomentose to appressed-puberulous or glabrous. Leaves spirally arranged to subdistichous; lamina oblong to lanceolate, (5-) 14-22 by (1.5-)4-8.5 cm, symmetric to slightly asymmetric, coriaceous, apex (sub)acuminate, base rounded to cuneate to subattenuate, margin entire, towards the base slightly revolute; upper surface (very) sparsely puberulous on (the base of) the midrib or glabrous, \pm shining when dry, lower surface (initially) brown subtomentose to appressed-puberulous on the main veins (and on the margin) or glabrous (except for the base of the midrib), smooth; cystoliths only beneath; midrib slightly prominent to plane above, lateral veins (10-)12-15 pairs, slightly impressed to plane, the basal pair \pm distinct, tertiary venation reticulate to subscalariform, the smaller veins slightly prominent beneath; waxy glands in the axils of the basal lateral veins; petiole $(0.5-) 1-1.5 \mathrm{~cm}$ long, brownish subtomentose or glabrous, the epidermis flaking off; stipules (1.5-)2-3.5 $\mathrm{cm}$ long, densely brown appressed-puberulous to subglabrous, caducous. Figs axillary, in pairs or solitary, sessile; basal bracts 3, verticillate, 2-4(-5) mm long, persistent; receptacle subglobose, $0.7-1.2 \mathrm{~cm}$ diam. when dry, non-stipitate, sparsely puberulous to glabrous, or (initially) brown tomentose, greenish at maturity, apex convex, ostiole c. $1.5 \mathrm{~mm}$ diam., \pm prominent, the upper ostiolar bracts glabrous or (initially) brown tomentose; internal hairs absent. Tepals red, glabrous. Stamens (1 or) 2.

\section{ACKNOWLEDGEMENTS}

Some of the data for this study have been acquired during a visit to herbarium E(dinburgh), financed by the European Commission's Research Infrastructure Action via the SYNTHESYS Project. Dr. J.F. Veldkamp (Leiden) translated the diagnosis into Latin.

\section{REFERENCES}

Berg, C.C. 2003. Flora Malesiana precursor for the treatment of Moraceae 2: Ficus subgenus Pharmacosycea section Oreosycea. Blumea 48: 289-301.

Berg, C.C. \& E. J.H. Corner. 2005. Moraceae - Ficus. Flora Malesiana, Ser. I, 17/2. Leiden. 